Journal of Sustainable Development of Transport and Logistics

journal home page: https://jsdtl.sciview.net

Karpenko, O., Horbenko, A., Vovk, Yu., \& Tson, O. (2017). Research of the structure and trends in the development of the logistics market in Ukraine. Journal of Sustainable Development of Transport and Logistics, 2(2), 57-66. doi:10.14254/jsdtl.2017.2-2.5.

\title{
Research of the structure and trends in the development of the logistics market in Ukraine
}

\section{Olena Karpenko* (D), Aleksandra Horbenko** (D), Yuriy Vovk*** (D),}

\section{Oleh Tson***}

* Logistic Management Center,

1, M. Omelianovycha-Pavlenka Str., Kyiv, Ukraine 01010

PhD, Co-Founder of Logistic Management Center

** Logistic Management Center,

1, M. Omelianovycha-Pavlenka Str., Kyiv, Ukraine 01010

PhD, Founder of Logistic Management Center

*** Ternopil Ivan Pul'uj National Technical University,

56 Ruska str., 46001 Ternopil, Ukraine

PhD, Associate Professor, Department of Transport Technologies and Mechanics

\section{open 0 access cc dol}

\section{Article history:}

Received: October 1, 2017

1st Revision: October 21,

2017

Accepted: October 29, 2017

\section{DOI:}

10.14254/jsdtl.2017.2-2.5

\begin{abstract}
The purpose of the article is to study the structure and capacity of the Ukrainian logistics market. Based on the use of statistical methods, mathematical modeling, forecasting, the main development trends of the market of logistics services in Ukraine are determined. The research results can be used both in scientific sphere and for making investment decisions in the practice of players of the Ukrainian market.
\end{abstract}

Keywords: Logistics, logistics market, development trends, market capacity, electronic commerce, transport.

\section{Introduction}

Rapid changes and trends in the world are reflected in the logistics market of Ukraine. Even with the collapse of national science, our country remains open to the consumption of the results of the progress of the leading countries. The only question is the amount of money ready to be spent by business owners on modernization. Since the socio-economic system of Ukraine is relatively unstable, it makes no sense to hope for foreign investors. Thus, overtaking technical modernization in this field is possible only with the use of internal resources.

For today there is no generalized indicator of Ukraine's logistics market. There are many studies based on official sources or highly specialized information. That is, there is no formalized data on the basis of which the investor would be able to realize his desire to invest in the development of competitive advantages of his own business.

Corresponding author: Olena Karpenko

E-mail: tanitriel@ukr.net

This open access article is distributed under a Creative Commons Attribution (CC-BY) 4.0 license. 


\section{Review of literature}

Market conditions research is a continuous process. Unfortunately, in Ukraine such studies are of a one-time nature and are carried out by scientists for the needs of scientific works, and by commercial agencies for the customer. Therefore, authors consider it incorrect to indicate a wide range of works that indirectly relate to the logistics market.

\section{Research methods}

Market research covers: competitors, consumers, prices, internal and external potential of market players. The basic principles of market research are general scientific, analytical and forecasting methods. Information support consists of the results of desk and field studies, as well as information from a variety of sources (internal and external, personal and paid).

\section{Research of the dynamics of macroeconomic indicators of the logistics market}

According to the defined methodology, the main macroeconomic indicators of the logistics industry in Ukraine are taken: the share of logistics services in world GDP (Table 1); index of prices of the logistics market (Fig. 2); staffing of the logistics market; investment potential of the logistics sector of the economy of Ukraine and others (Ministry of Finance of Ukraine, 2017).

To identify the share of logistics services in the GDP of Ukraine, the calculation was made for a group of countries with the exception of Europe, both Americas and the world average. For Ukraine the figure was $15.3 \%$. However, according to official statistics, the share under Transport, Storage, Postal and Courier Activities amounted to $6.63 \%$ of the total value of GDP. And during the ten-year period it did not exceed $11 \%$ (see Fig. 1).

Visually you can see a decrease in the share of the logistics market in the structure of GDP since 2010. However, these $3 \%$ are likely to be removed due to the recount of official statistics taking into account specific zones.

Table 1: Share of logistics services in world GDP

Countries

Share of logistics

services, $\%$

\begin{tabular}{lc}
\hline Russian Federation & 19 \\
Republic of Belarus & 12 \\
Republic of Kazakhstan & 16 \\
Republic of Moldova & 17 \\
Baltic States (average) & 12.1 \\
North America (average) & 8.67 \\
South America (average) & 11.9 \\
Europe (average) & 9.2 \\
Asia (average) & 13.5 \\
World average & 11.7 \\
Other countries (average) & 17.5 \\
Ukraine (estimate) & 15.3 \\
\hline
\end{tabular}

Since the authors believe that the official statistics carried out a proportional reduction of all items of income in GDP, one can conclude that the entrance to the logistics market in Ukraine is limited, as well as its ability to increase capacity.

Consequently, with such statistics, none of the investors (foreigner or Ukrainian) will have a desire to develop business. And if to refer to the Classifier of economic activities and find out that this 
$6-7 \%$ includes the volume of passenger traffic, then the picture is quite hopeless (EuroRating. Rating agency, 2016).

Therefore, in order not to discourage all the initiatives of innovators in the logistics industry, official statistics can be considered as a general tendency of the industry, rather than innovation and investment trends.

Figure 1: Share of logistics services in Ukraine's GDP (in \%)

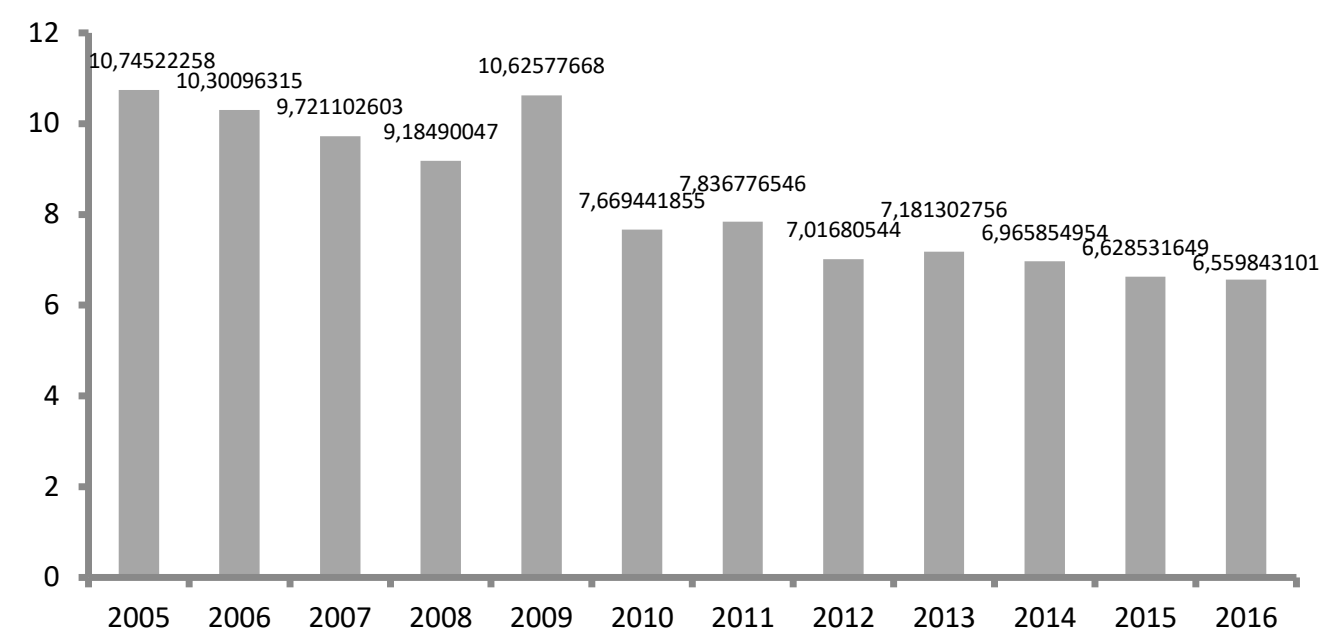

Hence, based on the results of the graphical analysis, it can be argued that the situation on the logistics market is stable and did not suffer a significant deterioration. But this indicator does not provide information about the real size of the logistics market. Therefore, in the future, the indicator of capacity (size) of the logistics market of Ukraine will be calculated experimentally.

Also, the main macroeconomic indicator of the market is the dynamics of prices for logistics services (see Fig. 2) (Ministry of Finance of Ukraine, 2017, State Service of Statistics of Ukraine, 2017).

From the graph we see that inflationary shifts have little effect on the price category of the market of logistics services. Significant increase was observed in tariffs for rail freight $(+35 \%)$ and postal services $(+20 \%)$, whereas prices for other types of transport and storage services increased by only $10-$ $13 \%$. Also, it should be noted that the consideration of this indicator reflects only the tendency of the logistics industry to be exposed to the overall changes in the socio-economic system of Ukraine.

Figure 2: Dynamics of price indices of the logistics market and inflation

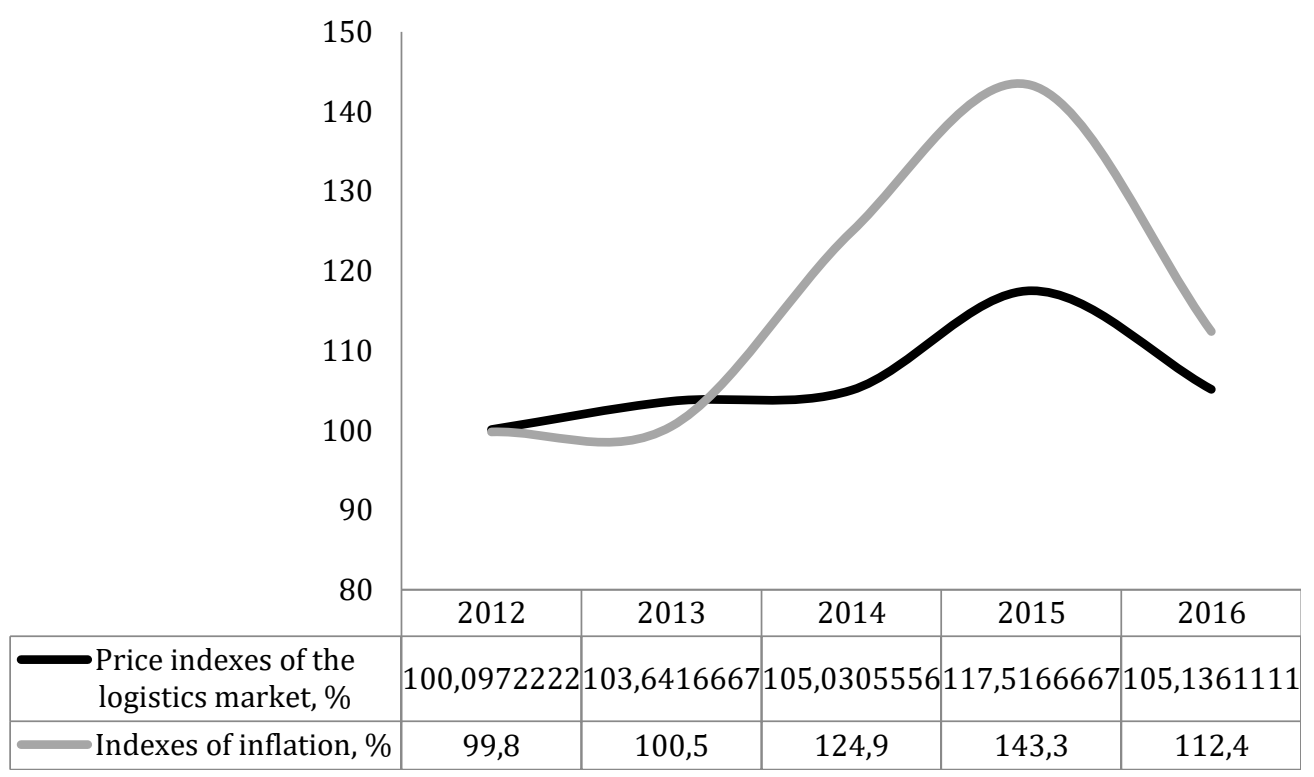

The research of the logistics market only on the part of monetary indicators is limited, therefore, when segmenting the market, indicators will be submitted in kind and in cash. 
The situation in the next graph (Fig. 3) reflects how inflation and the rise in the minimum wage level affected wage costs.

Figure 3: Dynamics of wages in the logistics industry

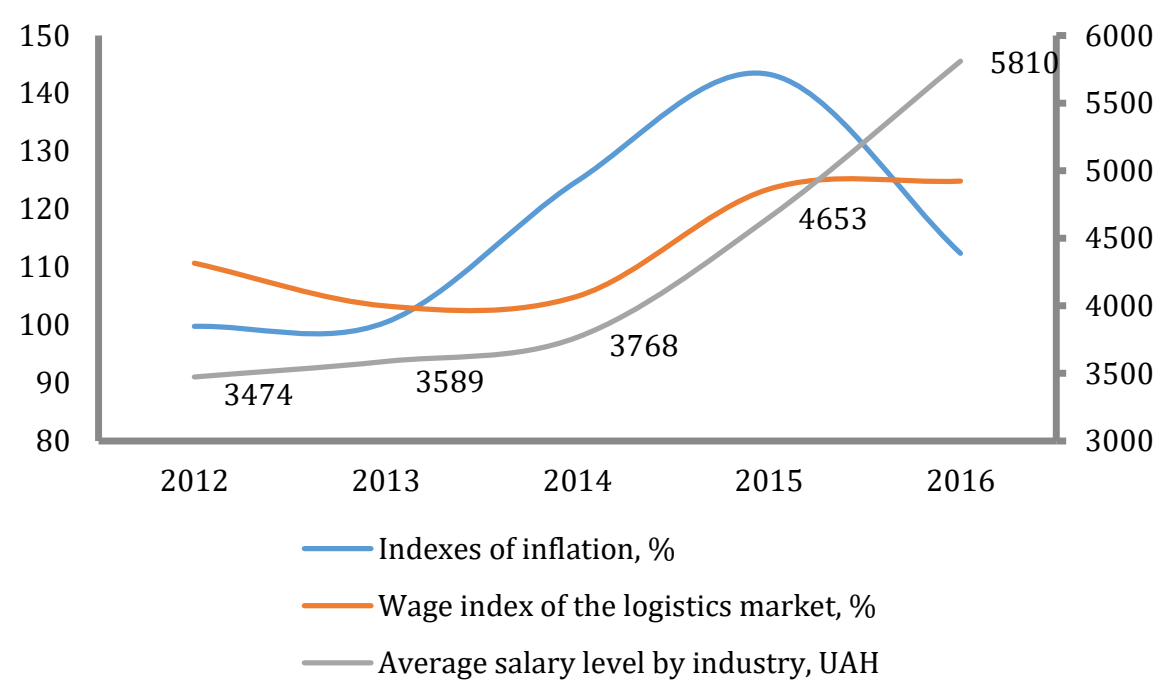

It is logical to argue that the tendency to increase wages was supported by the very UAH 3,200 , rather than the desire of business to increase wages.

And if to track trends in the wages on the logistics market, the employers' desire (offer - UAH 7,000 ) does not coincide with the requirements of the applicants (demand - UAH 9,000).

The situation with a demand for labor is also unbalanced. Employers in 2016 needed 3,800 people. The number of people wishing to work in this area was more than 100,000 CVs, while more than 18,000 people were employed in the same year. The most relevant vacancies are: sales manager of logistics services, logistician and warehouse workers. The last vacancy is clear, but there is a question regarding the first two. However, if we compare the wages and employment of these specialists, then the prospect of working at the warehouse becomes very attractive.

What else will interest the investor? Yes, fixed assets. The domestic investor knows that the indicator of $60 \%$ of the fixed assets depreciation in the current economic sector is much better than 10 years ago. But our capital resources frankly frighten foreigners.

Figure 4: Dynamics of capital investment in the logistics market

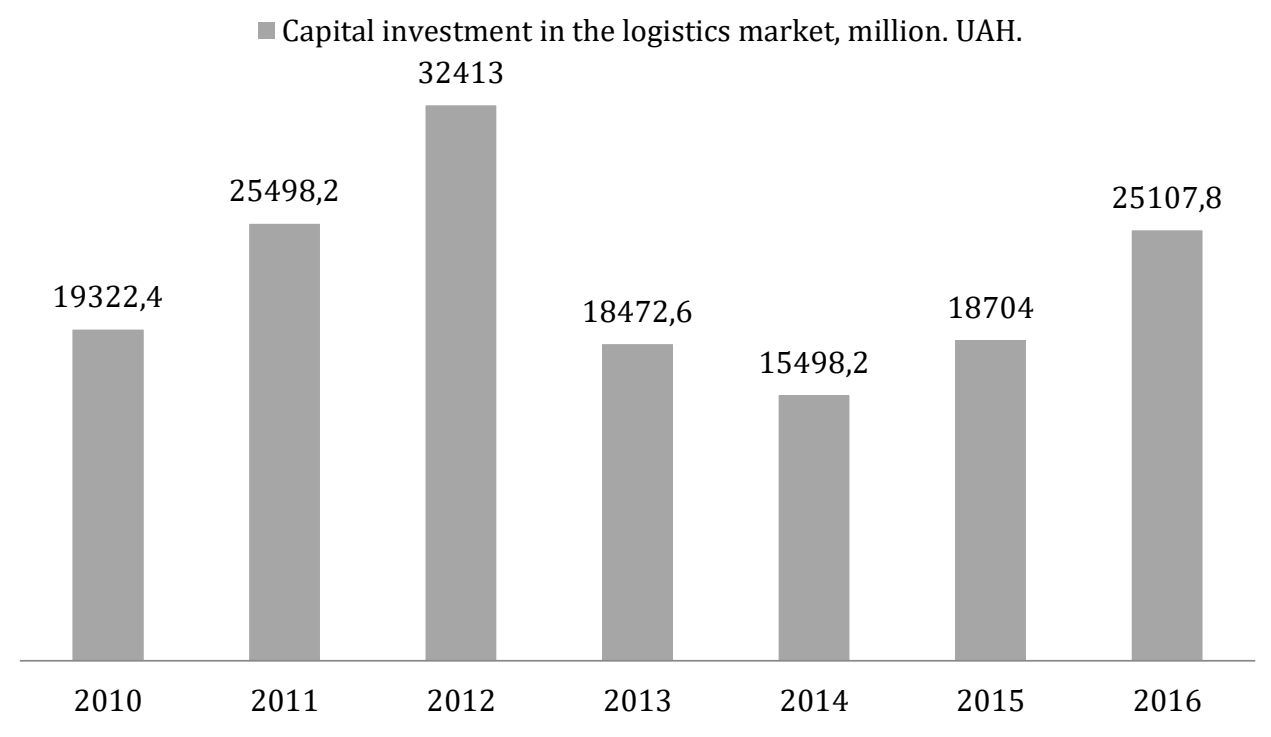


Integration into the EU and their increased demands on the environmental friendliness of fixed assets, as well as the quality of service provision, encourage the domestic "businessman-logistician" to renew fleets and storage facilities. This is evidenced by the structure of capital investments in 2016, in which $64 \%$ and $32 \%$ respectively are directed to ground transportation and storage.

As for the foreign investments, compared to 2015 , their level increased by $17.1 \%$, and amounted to USD 4.406 bln in 2016, USD $524.9 \mathrm{mln}$ of which were sent to the logistics sector. Unfortunately, logistics is not as attractive as the agro-industrial complex and IT. The largest amount of investments came from the Russian Federation, Cyprus and the United Kingdom.

Interesting is the fact that Ukraine itself has identified the priority areas for investing in the logistics market. But, it could possibly limit the entry of innovations and investors with various financial opportunities to the Ukrainian logistics market. Here are these areas:

Rail sector: creation of a network of interconnected logistics centers and multimodal terminals in large transport hubs, checkpoints across the state border of Ukraine and EU countries; purchase of freight wagons and operation of freight rolling stock.

Road sector: construction of new highways on the terms of concession and the mechanism of public-private partnership; development, implementation and application of the national transport model in the planning and implementation of the transport infrastructure development strategy; road management on the basis of geoinformation technologies.

Marine and river sector: construction of new and deepening of existing waterways and water areas of seaports for unimpeded passage of vessels of large deadweight; construction and use of river berths and locks, dredging; modernization and creation of port infrastructure facilities on the basis of long-term lease agreements, concessions, public-private partnerships, joint activity agreements, other investment agreements; creation and introduction of energy saving technologies on sea transport, introduction of plants for manufacturing alternative types of fuel; navigation support on inland waterways and provision of operative technological communication.

Aviation sector: development of the existing airport system, the runway at the aerodromes and their infrastructure; transfer of rights to own and use airport property in concession; renewal of aircraft fleet.

\section{Description of structural elements of the logistics market of Ukraine}

Since there is no single methodology for assessing capacity and segmenting the logistics market of Ukraine, it is proposed to conduct research on the following segments: transport logistics, storage logistics, contract logistics.

The market research of transport and logistics services was conducted and published earlier (Karpenko, Kovalchuk, Kuzmych, Gorpyniuk, \& Shevchuk, 2017), therefore, we give the final figures for this segment. The total capacity of the Ukrainian market of transport and logistics services is UAH $438.740 \mathrm{bln}$. The largest share belongs to road transport $75.92 \%$, which prevails in the domestic market. This indicates the orientation of Ukraine's transport logistics on domestic demand. In international traffic, the situation is somewhat different. The largest shares of $35 \%$ belong to air and sea transport, $20 \%$ to the railway, the remaining $10 \%$ are shared by the road (8\%) and river (2\%) types of transport.

Regarding the next segment of the logistics market of Ukraine - storage logistics, it has a distinctive feature in the division of this segment directly into warehousing and a range of logistics services. In 2005, there was no clear separation of storage logistics, however, at the moment, under the range of services we often mean contract logistics, which will be discussed in more detail in the next sub-point of the study.

The situation in the storage real estate market in 2016 is characterized by changing the negative trend of the past years to stabilization of the situation on this market segment. According to Colliers International, there has been a positive trend in the equalization of demand among tenants, a number of operations on purchase of large storage facilities have been carried out, and there has been a moderate tendency to reduce vacancy and stabilize rental rates.

Demand for storage facilities is formed by the logistics and trade operators. As a change in the market, we can note an increase in the interest of tenants and developers of storage real estate in the regions. 
The leading position in the segment of storage logistics takes Kyiv and Kyiv region. In the storage facilities rental market in Ukraine, Kyiv and Kyiv region occupy $56.10 \%$, which exceeds the offer in other regions, but compared to 2015 (81.06\%), almost $30 \%$ of the offer moved to the regions.

However, in terms of sales of storage real estate the picture is significantly different. Undoubtedly, Kyiv region has a higher share in sales, however, does not significantly exceed the offer of other regions, as seen in the case of rent.

Figure 5: Regional structure of the offer of storage facilities of A and B class

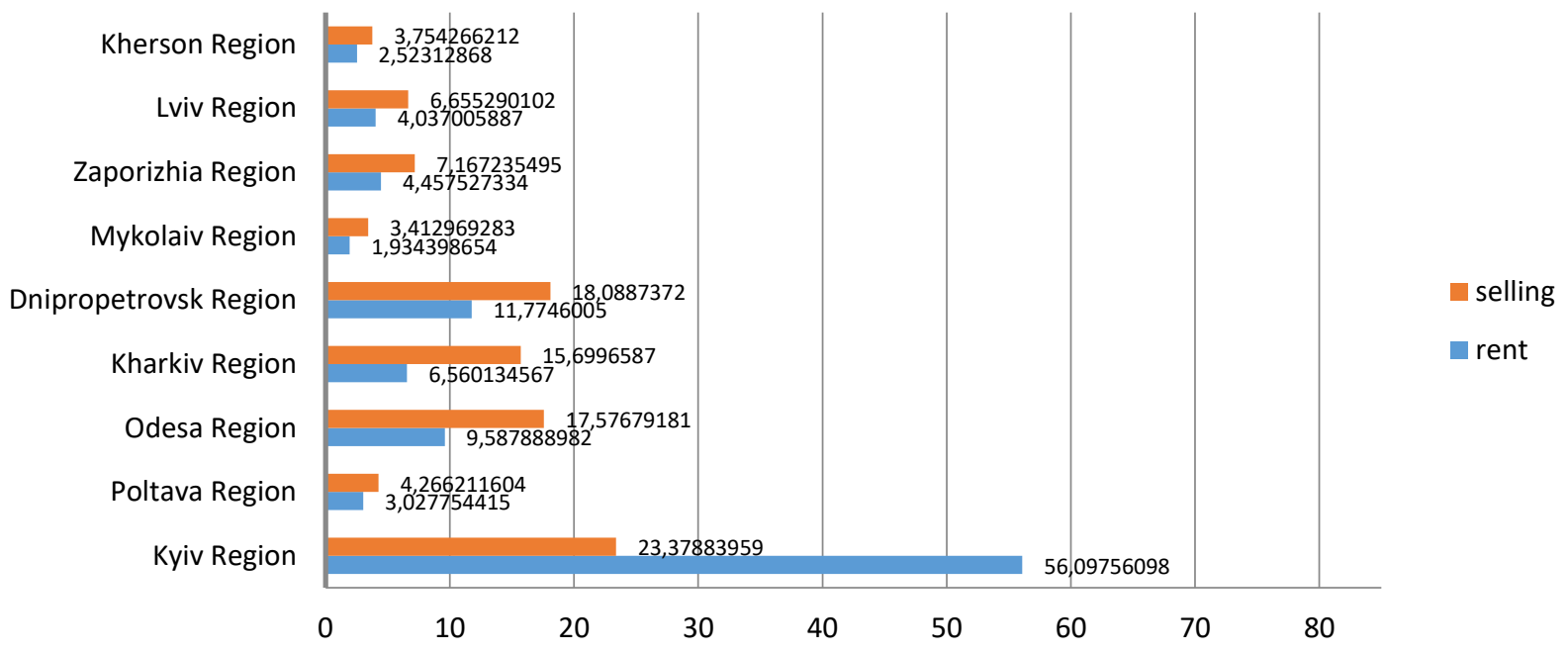

Excess of sale over rent can mean both lack of desire of owners to maintain the unclaimed real estate, and revival of the market of logistics at the regional level.

Figure 6: Structure of the construction of commercial real estate by regions

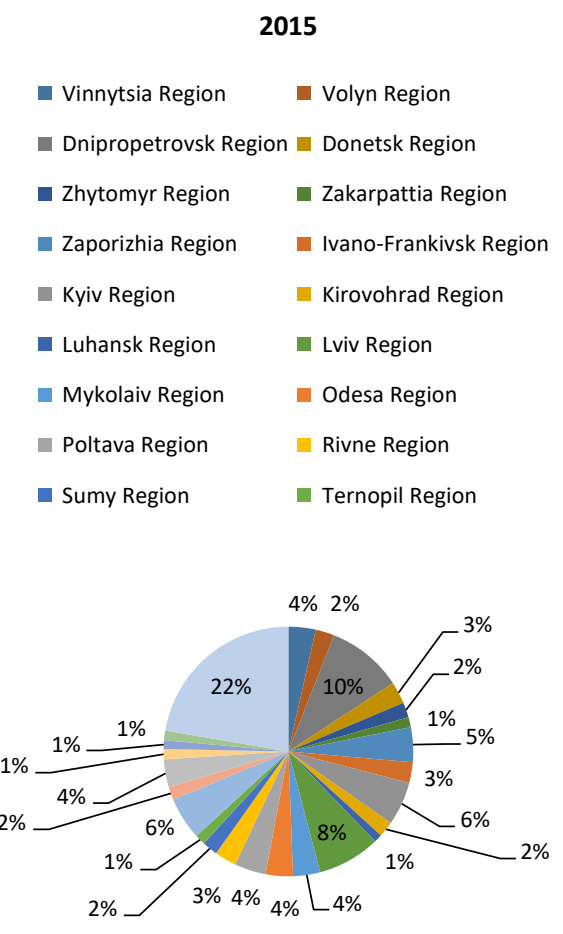

a)
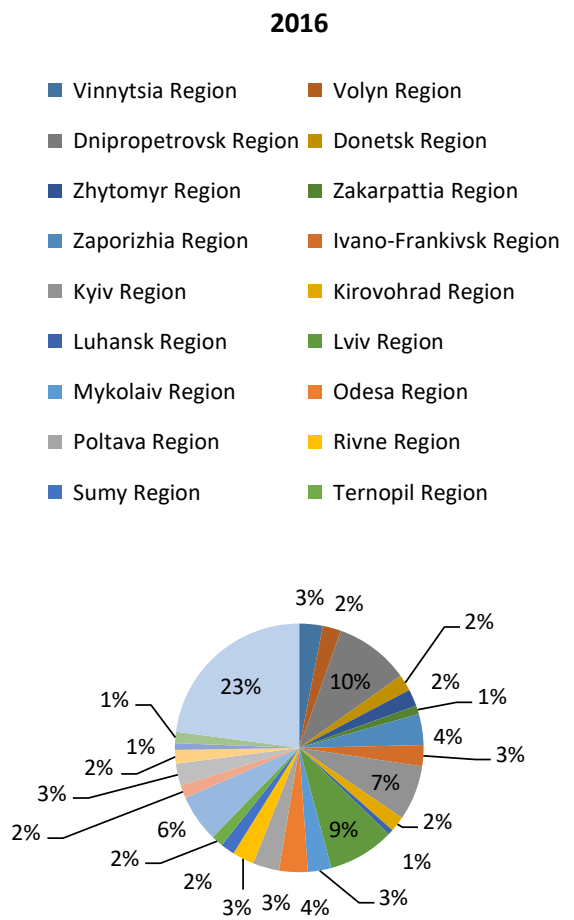

b)

Graphical analysis reflects the situation described above. The interest of developers has shifted from the central part of Ukraine to the regions. However, comparing the flow of investment in the construction of commercial real estate in 2016 to 2015, there was a decline in investment growth rates 
in the western regions, in particular: Volyn, Transcarpathian, Rivne, Ivano-Frankivsk regions. The increase in capital investments occurred in the following regions: Mykolayiv, Kirovograd, Sumy, Chernigiv, Kharkiv and Odesa.

Figure 7: Growth rate of investments in the construction of commercial real estate

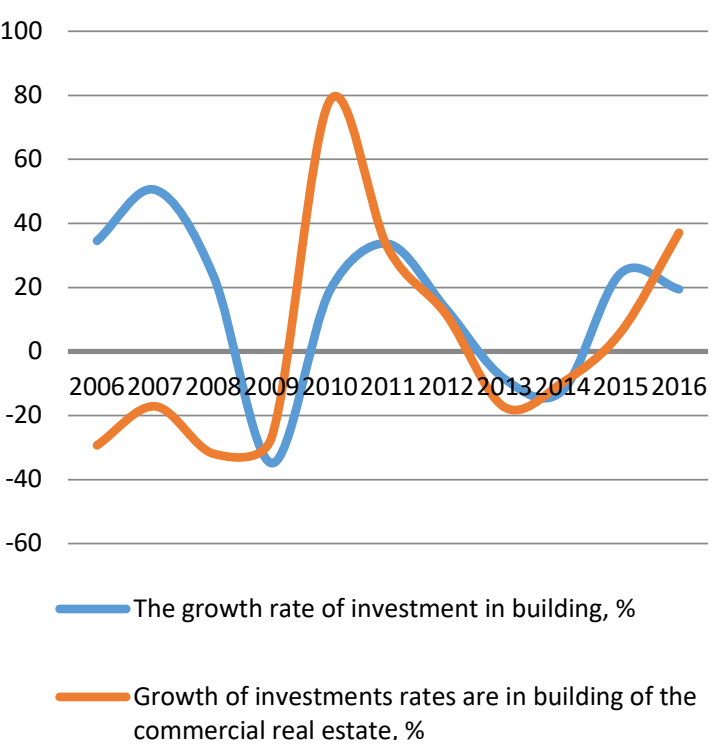

a)

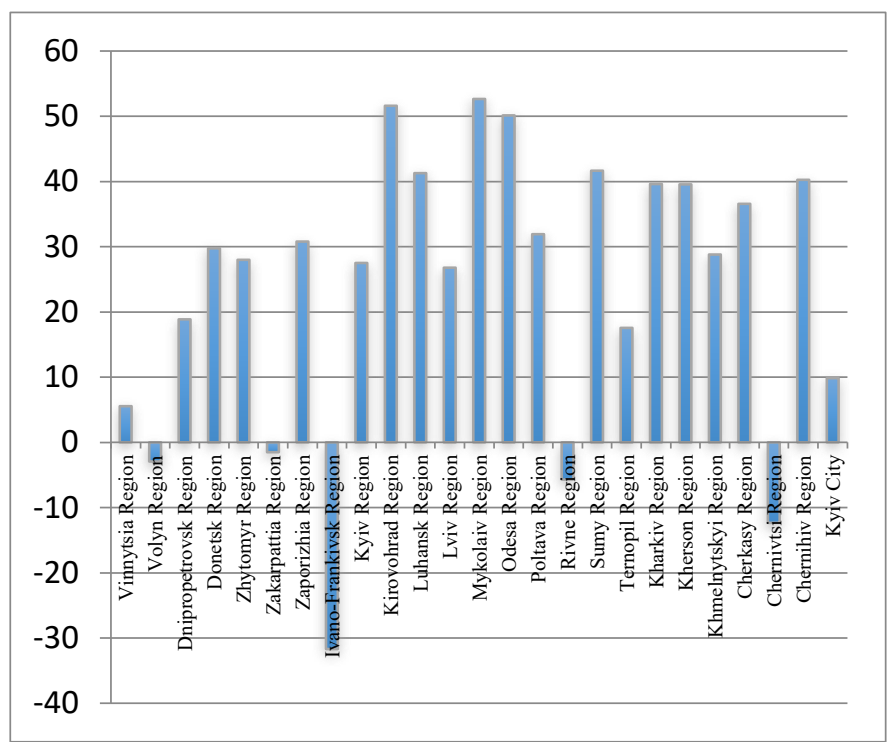

b)

Also, considering the structure of investment in the construction of commercial real estate, it can be noted that most of the cash flows are in Kyiv, Kyiv region and Dnipropetrovsk region. 5\% of investments are directed to Lviv, Kharkiv and Odesa regions, other regions are characterized by investment level less than 3\%. These explicit leaders of the segment are characterized by the identical rental rates: for A class - USD 3.5-4 USD per 1 sq.m, and for B class - USD 2-3 per 1 sq.m.

Figure 8: Dynamic trends in storage real estate market

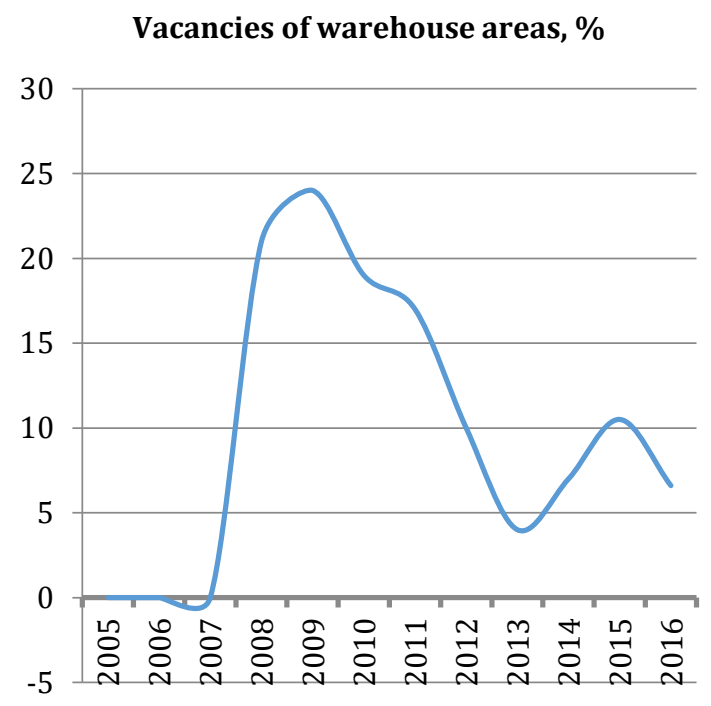

a)
Average rents, USD

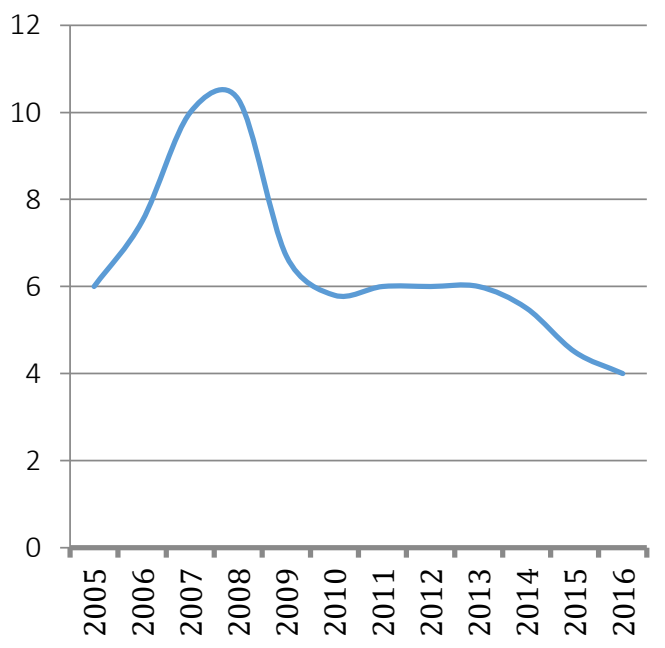

b)

At the end of the year, the total offer of universal storage facilities in Kyiv and Kyiv region reached about $16.8 \mathrm{mln}$ sq.m, while the rental rate for this region is USD 4. Thus, in terms of value, storage logistics market for this region contains UAH $181.44 \mathrm{bln}$. And since its share is $56 \%$ of the Ukrainian storage logistics market and the remaining rates are less by a quarter, the residual capacity will be UAH 106.920 bln (the total capacity is UAH 288.3 bln UAH). 
The authors investigated the market of contract logistics with the group of experts of the Ukrainian Logistics Alliance and doubt about some of the methodological aspects of the research. Therefore, the authors consider it impossible to use a complete database. In the future, it is planned to conduct an identical research with the experts of the Center and business players. But to represent the overall picture a percentage, which was made public in the media and logistics activities, will be taken. According to the conducted researches it was established that the contract logistics of Ukraine makes up almost $9 \%$ of the total structure of the logistics market. So, the market segments of transport and storage facilities make up $81 \%$ in the structure of the logistics market, amounting to UAH $727.1 \mathrm{bln}$. In money terms contract logistics amounted to UAH 65.44 bln in 2016. Thus, the total capacity of the logistics market was UAH 792.540 bln.

\section{Potential for the development of the logistics market in Ukraine.}

Forecasts of many research companies and special departments of individual transport and logistics operators converge in areas that are worthy of attention when making development strategies. A good illustration is Logistic radar from DHL, which fixes key areas for the development of transport and logistics services (Horbenko, 2017).

Among the potential directions of development of transport and logistics services are:

Applying the principles of multimodal logistics within cities. One of the tasks set in the EU Transport 2050 Roadmap: 30\% of road transport freight of more than $300 \mathrm{~km}$ long should be redirected by 2030 to rail or water transport, and $50 \%$ by 2050 . So it is about the implementation of principles of multimodal logistics within cities.

Practical examples show that combined transport modes can not yet compete with road transport, due to cost and time constraints (especially for shorter distances). However, in the corporate world, there is a growing consensus that higher short-term costs associated with more sustainable vehicles can be justified by long-term benefits. The European Commission supervises and already co-finances the implementation of the 9 strategic transport corridors within its TEN-T program. Particular interest in such projects is shown by such sectors of the economy as: construction materials and road sector due to the nature of supplies (heavy and bulky goods).

The global nature of world trade is based on the on-demand principle (at the request of the consumer), and as a consequence, there is an expansion of ways of delivering products in the logistics of the "first and last mile". The on-demand principle implies the fastest and most inexpensive satisfaction of consumers' demand on the basis of temporary use (not ownership of the product/service). Modern ecommerce, the basis of which is the service character of working with the consumer, is based on the ondemand principle.

Companies that connect their activities with the provision of services of a service nature, that is, those that have added value, receive greater profitability than those who work in the traditional manner of the business (FedEx, Ford, and Walmart). However, if the basis of the company's activities is the work with raw materials, products/services without the possibility of added value, then the output can be diversification of services, namely their customization (targeting on customers/consumers).

For transport and logistics companies, this customization is primarily related to the speed of delivery and the expanded options for obtaining goods, that is, new delivery methods.

The global growth of e-commerce and the further development of logistics of distance trading and related tools (in particular fulfillment and cross-docking services). According to the World Trade Organization, the pace of development of e-commerce at the moment is much higher than the rate of development of world trade in general. E-commerce as a channel for the sale of products continues to influence the transformation of distribution and logistics systems in general.

The United States and China are now the leaders in terms of trade. According to experts' forecasts, after 2016, Argentina, Mexico, Brazil, Russia, Italy will also come forward. At the same time, the growth rate of China's e-commerce will remain high.

All this affects the traffic flows in logistics. Thus, logistics in international trade is carried out by large transport companies with a functional not lower than 3PL. In the domestic market logistics in the distance trade is carried out by small operators of courier services and postal logistics operators who historically are engaged in logistics services of the "last mile". 
Widespread use of cloud technologies and data centers in the trade and management of commoditymaterial flows; development of omni-channel trading.

The direction of Big Data (Big Data: from a few terabytes to hundreds of terabytes) began to evolve in response to the need to collect, store and analyze ever-growing arrays of user data and their goods. Big Data is reflected in the development of electronic services for tenders in the G2B, B2B sectors (Karpenko, Kovalchuk, \& Shevchuk, 2016). In Ukraine, the capacity of this segment is estimated at UAH 250 bln per year. The most famous platform is the electronic system ProZorro, launched jointly by state structures, public organizations and private companies. The basic principle is "everyone sees everything": trades and other procedures are de-monopolized and pass through private trading platforms, such as e-tender.biz, dz.prom.ua, smarttender.

In addition, Big Data is an indispensable tool for the development of omni-channel trading. This is directly related to logistics, since the main idea of the omni-channel trading is to provide a single price, reliable and up-to-date information about its products in all sales channels (online and off-line), to provide the buyer the opportunity to choose the most convenient way of communication and to provide an opportunity to complete the transaction, regardless of the communication channel with the delivery of goods.

Green technologies and innovative solutions in logistics. These include solutions related to new environmental standards, such as: switching to alternative fuels (electric motors), the ban on the use of plastic bags in retail chains, the use of solar, wind energy, etc., new packaging recycling systems and approaches to packaging, development of technologies such as "smart container", the introduction of drones, further robotization of operational processes.

\section{Conclusions}

According to the results of the study, the authors found that in 2016 the capacity of the logistics market amounted to UAH $792.540 \mathrm{bln}$. That is, the capacity of this market is much larger than indicated in official sources, making it more attractive for investment. In addition, there are a number of promising areas in logistics that require significant investments.

In logistics, such technologies include: digitalization (mobile application) of transportation and storage processes; autonomous unmanned containers - the SEAtrue project, developed by a group of Norwegian graduate students: robotic containers capable of delivering goods to a port on floating platforms; electric transport for logistics of the "last mile" - back in 2015, the California Air Resources Board in its own research showed that electric vehicles will be widely used in the future; drones for delivery are tested by many foreign and domestic companies, but so far the projects have not started. There are certain restrictions on the part of legislation, including the use of unmanned vehicles in public life and business; Green technologies for working with containers are often observed in logistics.

\section{Appendix A. Supplementary material}

Supplementary data associated with this article can be found, in the online version, at https://jsdtl.sciview.net

\section{Funding}

The authors received no direct funding for this research.

\section{Citation information}

Karpenko, O., Horbenko, O., Vovk, Yu., \& Tson, 0. (2017). Research of the structure and trends in the development of the logistics market in Ukraine. Journal of Sustainable Development of Transport and Logistics, 2(2), 57-66. doi:10.14254/jsdtl.2017.2-2.5.

\section{References}

EuroRating. Rating agency. (September 13, 2016). The rating of investment efficiency of the regions of Ukraine for the second quarter of 2016: the gap between leaders and outsiders is growing. Retrieved from http://euro-rating.com.ua/rejting-investitsionnoj-effektivnosti-oblastej- 
ukrainy-po-itogam-vtorogo-kvartala-2016-g-razryv-mezhdu-liderami-i-autsajderami-rastet/ (Date of appeal: October 1, 2017).

Horbenko O. (2017) E-trade in Ukraine: Surfing Trends in Distribution and Logistics. Retrieved from http://logist.fm/publications/e-trade-ukraine-serfing-trendov/ (Date of appeal: October 1, 2017). (in Russian)

Karpenko, O.A., Kovalchuk, S.O., \& Petunin, A.V. (2015). Problems of scientific approach in the management of suppliers. Project management, systems analysis and logistics, 16(2), 19-26. (in Ukrainian).

Karpenko, O., Kovalchuk, S., \& Shevchuk, O. (2016). Prospects on Ukrainian logistics market orientation for international customers. Journal of Sustainable Development of Transport and Logistics, 1(1), 27-33. doi:10.14254/jsdtl.2016.1-1.5

Karpenko, O., Kovalchuk, S., Kuzmych, V., Gorpyniuk, A., \& Shevchuk, O.(2017). Current state and nearterm prospects for development of the transport logistics market in Ukraine. Journal of Sustainable Development of Transport and Logistics, 2(1), 51-60. doi:10.14254/jsdtl.2017.21.5 .

Ministry of Finance of Ukraine (March 22, 2017). Gross Domestic Product of Ukraine. Retrieved from http://index.minfin.com.ua/index/gdp/ (Date of appeal: October 1, 2017).

Ministry of Infrastructure of Ukraine (2016). Statistical data on the Ukrainian railways. Retrieved from http://www.mtu.gov.ua/content/statistichni-dani-pro-ukrainski-zaliznici.html (Date of appeal: October 1, 2017).

Popovych, P. (2016). Analytical technologies in ensuring the economic efficiency of logistics systems. Herald of HNTUSG, 169, 223-225.

State Service of Statistics of Ukraine. (2017). Economic statistics / Economic activities / Transport. Retrieved from: http://www.ukrstat.gov.ua/operativ/menu/menu_u/tr.htm (Date of appeal: October 1, 2017).

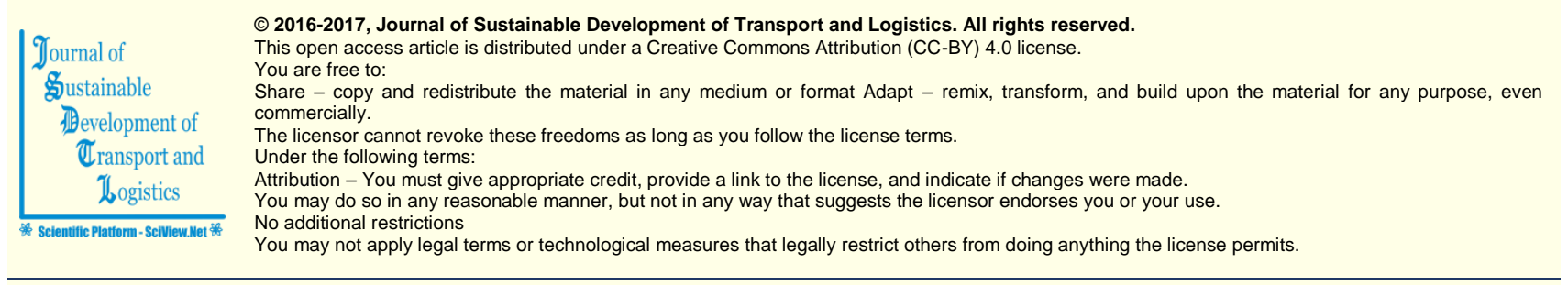

Journal of Sustainable Development of Transport and Logistics (ISSN: 2520-2979) is published by Scientific Publishing House "CSR", Poland, EU and Scientific Publishing House "SciView", Poland, EU

Publishing with JSDTL ensures:

- Immediate, universal access to your article on publication

- High visibility and discoverability via the JSDTL website

- Rapid publication

- Guaranteed legacy preservation of your article

- Discounts and waivers for authors in developing regions

Submit your manuscript to a JSDTL at http://jsdtl.sciview.net/ or submit.jsdtl@sciview.net 